\title{
Characterization of West African Jet Streams and Their Association to ENSO Events and Rainfall in ERA-Interim 1979-2011
}

\author{
Churchill Okonkwo, Belay Demoz, and Sium Tesfai \\ Beltsville Center for Climate System Observation, Atmospheric Science Program, Howard University, Washington DC, DC 20059, USA \\ Correspondence should be addressed to Churchill Okonkwo; churchill.okonkwo@bison.howard.edu \\ Received 15 November 2013; Revised 9 January 2014; Accepted 10 January 2014; Published 5 March 2014 \\ Academic Editor: Sven-Erik Gryning \\ Copyright (C) 2014 Churchill Okonkwo et al. This is an open access article distributed under the Creative Commons Attribution \\ License, which permits unrestricted use, distribution, and reproduction in any medium, provided the original work is properly \\ cited. \\ The interannual variability of West African jet streams and their association with rainfall are reexamined using European Reanalysis \\ ERA-Interim 1979-2011. The objective of the study is to characterize their climatology and role in rainfall variability in western Sahel. \\ Wavelet analysis was used on wind speed data and implications to ENSO were discussed subsequently. Our results show that while \\ the low-level African Westerly Jet (AWJ) correlates well with rainfall south of the equator in boreal winter months, the Tropical \\ Easterly Jet (TEJ) and African Easterly Jet (AEJ) correlate better with rainfall north of the equator in the boreal summer months. \\ Results of interannual-to-decadal variability in $200 \mathrm{mb}, 600 \mathrm{mb}$, and $850 \mathrm{mb}$ of zonal wind reveal that there is enhanced variability \\ in the 2-8 year band. Also, the TEJ, AEJ, and AWJ fluctuations are coupled with variations in southern oscillation. Further analysis \\ suggests a statistically significant association between TEJ and the El Niño events of the 1980s that led to intense drought in the \\ Sahel region of West Africa. The 2007 moderate La Niña shows a statistically significant coherence with the $500 \mathrm{mb}, 600 \mathrm{mb}$, and \\ $850 \mathrm{mb}$ jets. These associations are also phase locked, suggesting that the association may be more than by chance.
}

\section{Introduction}

The Sahel region in West Africa is characterized by severe drought and a sharp decrease in rainfall from equatorial West Africa to the southern edge of the Sahara desert (Figure 1). Over the past three decades, studies on the possible causes of drought in Sahel have either focused on forcing by sea surface temperature (SST) [1] or land-atmosphere interaction [2]. Simulations of the hydrological impact of land surface processes studies include Charney [3] YongKang Xue and Shukla [4], Taylor et al. [2], and Li et al. [5], which all attributed reduced rainfall to degradation of land surface at least in part. As the forest and shrubs are cleared and burnt prior to cultivation, the vegetation that absorbs incoming solar radiation is removed with a resultant increase in albedo. According to Charney [3], land cover with elevated albedo has a more stable air column, which suppresses precipitation unlike surrounding areas. This mechanism is extended leading to self-stabilization of desert in the Sahel region [3]. The contribution of these mechanisms has however been overstressed [6] especially the characterization of desertification in the Sahel as irreversible. Subsequently, Eklundh and Olsson [7], Polgreen [8], and Herrmann et al. [9] have all confirmed recent greening in Sahel. Their studies show that vegetation under stress due to inadequate rain can recover quickly with improved precipitation.

There have also been several studies that examined the teleconnection between rainfall variability in Sahel and variation in global sea surface temperature (SST) [1]. While it has been accepted that SST patterns play a significant role in rainfall variability in West Africa [1,10-12], there is still a debate regarding the major drivers [13]. Several reports have found that regional circulation patterns forced by SST of the North Atlantic have more influence on the local climate in the Sahel region [1,14-17] than changes in land use.

In addition to the above teleconnection, the role of the Mediterranean [18] as having a strong influence on precipitation across the Sahel has been reported. On the other hand, the influence of the Indian Ocean on both Sahel rainfall and Indian monsoon has also been suggested [19]. Studies 
on the role of El Niño Southern Oscillation (ENSO) events and Pacific index in modulating Sahel precipitation include those of Rowell [20], Caminade and Terray [21], and Joly et al. [22]. One of the conclusions that came out of these multiple studies is that the interannual to decadal variability in precipitation over West Africa is controlled by competing physical mechanisms [23]. These physical mechanisms have been summarized by Caminade and Terray [21] into two broad conditions; (1) those that enhance precipitationpositive (negative) SST anomalies north (south) of equator, as increased water vapor holding capacity, and La Nina eventand (2) conditions that are less favorable to precipitation such as negative (positive) SST anomalies north (south) of equator and El Nino events.

Recently, the strong link between Sahel region and West African monsoon-the precursor to most of its rainfallhas been reexamined [24-26]. Of particular importance are the shortcomings of the classical picture of the West African monsoon and the association of the rainfall to the Intertropical Convergence Zone (ITCZ). Some of these shortcomings include the association of rainfall with the convergence of southwest monsoonal flow and the northeasterly Harmattan wind with the increasing movement of deep moist layer equator-ward from the ITCZ $[27,28]$. This concept is, however, less likely because it originates from the Hadley circulation cell which is valid over the ocean [25] and describes the global mean state rather than regional [13]. Also, the association of ITCZ to several variables (surface pressure, wind convergence, and rainfall) makes its use in characterizing the West African monsoon ambiguous. Following the discussion, the classical picture of the West African monsoon has been revised and ITCZ is interchangeably being used with "tropical rainbelt" [24] and "rain band" [25]. The revised picture of West African monsoon is pointing to a diminished importance of ITCZ in controlling precipitation while emphasizing the role of African easterly jet (AEJ), tropical easterly jet (TEJ), and low level westerlies as some of the main tropical circulation features in the region [24-26].

Despite these advances on the possible causes and trends of persistent drought in the Sahel region, there are still projection uncertainties and models cannot reliably predict future climates in the region $[10,12]$. This led to a large spread in projections $[27,28]$. This is partly due to the complexity in dynamics from the AEJ to TEJ, which makes prediction of precipitation difficult [29]. To better simulate the West African monsoon and improve in precipitation projection, a good understanding of the complexity of the West African monsoon dynamics is vital.

In this paper, we used the improved ECMWF-Interim reanalysis data 1979-2011 (hereafter referred to as ERAInterim) to provide further details on the annual to interannual variability of the West African jet streams. The objective of this first of two parts study is to represent more accurately the jet streams and characterize their climatology and role in rainfall variability in Sahel using ERA-Interim. This study differs from previous studies by applying wavelet statistical analysis to height versus time output of $200 \mathrm{mb}, 500 \mathrm{mb}, 600 \mathrm{mb}$, and $850 \mathrm{mb}$ U-wind to study how the jet streams modulate precipitation with emphasis on the $2-8$ year timescale

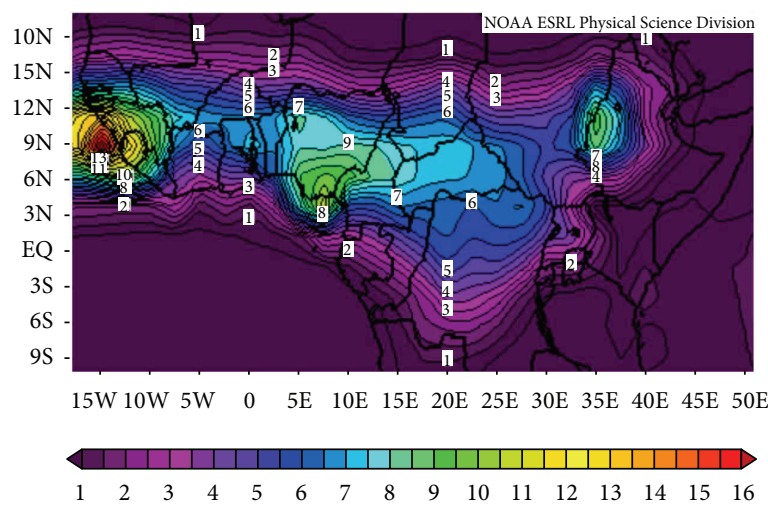

Figure 1: July, August, and September (JAS) precipitation (mm/month) averaged from 1979 to 2010 (data source: GPCP; this figure was created using the NOAA/ESRL Physical Science Division website (http://www.esrlnoaa.gov/psd/cgi-bin/data/composites/printpage.pl).

typically associated with ENSO events. The organization of the paper is as follows. Section 2 describes the data and correlation methodology. Section 3 describes the results under annual cycle, interannual to multidecadal cycle, and jet stream association with ENSO. Summary and conclusions will be presented in Section 4.

\section{Data and Methodology}

The primary dataset used for this study was the ERAInterim reanalysis $\left(1.5^{\circ} \times 1.5^{\circ}\right.$ resolution $)$ [30]. This global reanalysis provides meteorological variables needed for a better understanding of West African monsoon circulation and precipitation. The ERA-Interim output data were used in this analysis because of the absence of detailed longterm observational wind data. According to Dee et al. [31] (2011), the ERA-Interim data assimilation system consists of a 12 hourly $4 \mathrm{D}$-Var of the upper-air atmospheric state. In regions where observations are sparse, like the Sahel region in the study domain, the ability of ERA-Interim's data assimilation system to exploit physical information implicit in the model equations can be advantageous [31]. The 4DVar in ERA-Interim has been shown to outperform 3D-Var of ERA-40 in such situations [32,33].

Ancillary data used in this work also includes the Global Precipitation Climatology Project (GPCP; World Climate Research Program 1990), a one-degree daily estimate of precipitation. The GPCP data (merged from satellite and a gauge observation) is an excellent validation for precipitation produced by models [34].

This study is focused primarily on the West African monsoon circulation and rainfall. We, therefore, examined the latitude-month variations of zonal wind fields from reanalysis zonally averaged over the longitudinal domain $18^{\circ} \mathrm{W}-35^{\circ} \mathrm{E}$ to determine the spatial and temporal distribution of precipitation across the study domain. As part of the data preparation, we considered the different regional climatologies within the study domain and thus averaged the 
mean monthly values over a broad range to minimize effects that result from mesoscale phenomena following Liang and Wang [35]. Some of these mesoscale phenomena in the West African region include orographic effect, mesoscale convective systems, and dust storms. Jet streams (a multiscale nonstationary process) are nonstationary in nature with a variety of changes that could occur as it moves north and south with seasons with different localizations in time and frequency. The interannual variability of these jet streams with ENSO events was examined using wavelet analysis. This was achieved by decomposing jets time series into frequency space following the program developed by Torrence and Compo [36] and Grinsted et al. [37].

The wavelet transform is given as

$$
\mathscr{W}(\tau, s)=\frac{1}{(s)^{1 / 2}} \int_{-\infty}^{+\infty} X(t) \psi^{*}\left(\frac{t-\tau}{s}\right) d t,
$$

where $\psi(t)$ is the mother wavelet defined by $\tau$, the transition parameter corresponding to the position of the wavelet, and $s$, the scale dilation parameter that determines the width of the wavelet. The variability of the dominant mode with time was determined using the Morlet wavelet with a wavenumber $w_{0}=6$ as the mother wavelet. The choice of Morlet wavelet is based on its localization in time and frequency, making it a good tool in extracting features [37]. Information about the periodicity of the time series data can be extracted from the continuous wavelet transform (CWT). For details of the basic theory of CWT, see [36, 37].

\section{Result}

3.1. Annual Cycle. ERA-Interim rainfall data is not suitable for annual cycle studies since the model-derived precipitation is overly affected by model parameterization [38]. The GPCP rainfall data, which is a gauge satellite merged product, is used instead. We first characterize the rainfall climatology in the latitude-month variation, zonally averaged over the longitudinal domain $18^{\circ} \mathrm{W}-35^{\circ} \mathrm{E}$ (Figure 2 ). Heavy rainfall occurs predominantly north of the equator while dry conditions are common south of the equator between June and September. Two characteristic rain-bands can also be identified. South of the equator, there is a distinct rainy season between the months of December through March. The second rain-band is north of the equator between $0^{\circ}$ and $20^{\circ} \mathrm{N}$. For the Sahel region $\left(14^{\circ} \mathrm{N}-18^{\circ} \mathrm{N}\right)$, there is a shot raining season-July to September-with mean rainfall of $4-6 \mathrm{~mm}$ /day (Figure 2). This characteristic short raining season can lead to famine in drought years.

Figure 3 shows the three major jets over the West African region, namely, the TEJ, AEJ, and LLJ focused on West African Jets (WAJ) in this study. The upper level Tropospheric Easterly Jet-TEJ-is most intense at $250 \mathrm{mb}$ (Figure 3(a)) with the core near $5^{\circ} \mathrm{N}-8^{\circ} \mathrm{N}$ (Figure $3(\mathrm{a})$ ). The AEJ has a core over the West African Sahel centered between $12^{\circ} \mathrm{N}-$ $20^{\circ} \mathrm{N}$ with a secondary weaker eastern core (Figure 3(b)). There is latitudinal variability in the structure of AEJ in agreement with Hall et al. [39]. Dezfuli and Nicholson [40] have described the merging of these two cores occasionally.

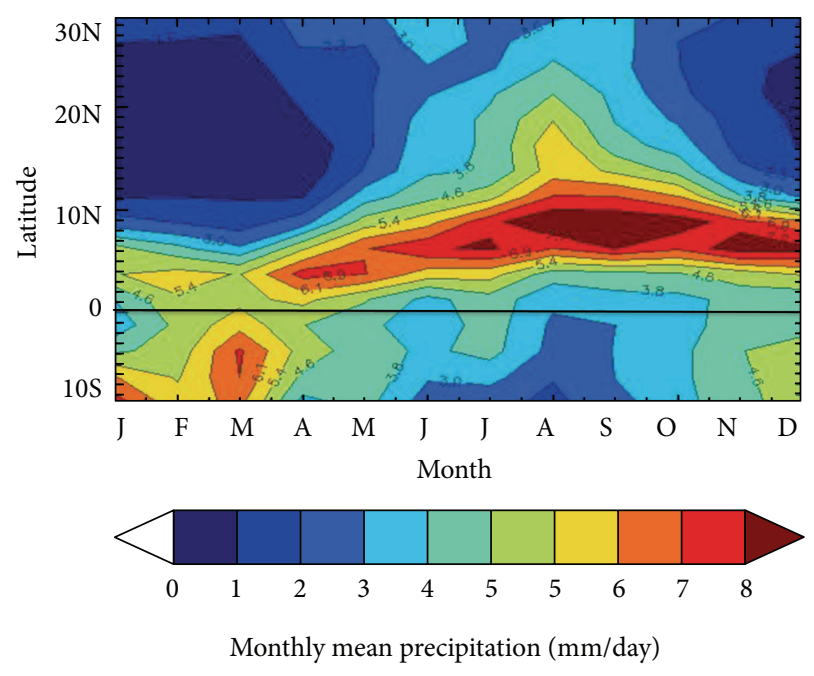

FIGURE 2: Observed latitude-month annual cycle of rainfall (mm day $^{-1}$ ) zonally averaged between latitudes $18^{\circ} \mathrm{W}$ and $35^{\circ} \mathrm{E}$ (data source: GPCP).

The West African Jets (WAJ) appears as near surface wind in the order of 2 to $4 \mathrm{~ms}^{-1}$ (Figure 3(c)). A detailed review of these jet streams can be found in Nicholson [13].

Figure 4 shows the seasonal cycle of zonal wind speed at the peak pressure levels of the jets. The AWJ are the equatorial westerlies described by Grist and Nicholson [41] with westerly speeds up to 2 to $4 \mathrm{~m} \mathrm{~s}^{-1}$ [13]. The WAJ are well developed in the months of May through October and June through September in the $1000 \mathrm{mb}$ and $850 \mathrm{mb}$ winds, respectively (Figures 4(a) and 4(b)). Starting in May, the LLJs strengthen and migrate north during the seasonal march. It has its core near $9^{\circ} \mathrm{N}$ in the month of August and is strongest at the $850 \mathrm{mb}$

AEJ plays a role in generating African Easterly Waves, which contribute to West African monsoon precipitation $[13,42,43]$. The $600 \mathrm{hPa}$ and $500 \mathrm{hPa}$ are the midtropospheric pressure levels where AEJ reaches maximum wind speeds in boreal summer $[43,44]$. As such, we analyzed the AEJ at the $600 \mathrm{hPa}$ and $500 \mathrm{hPa}$ (in wavelet analysis) levels. The AEJ is strong in the months of JJAS with mean speed in the order of $5 \mathrm{~ms}^{-1}$ (Figure 4(c)). The wind speed decreases as it makes the seasonal march northwards through the Sahel region. The temperature gradient between the Atlantic Ocean to the south and the Sahara to the north [45], Sahara high [46], has been linked to the existence of AEJ with its intensification associated with moist processes [47].

The TEJ core strengthens from May to September with maximum intensity during the regional raining seasonsummer months (JJAS) (Figure 4(d)). During this period, there is minimal rainfall over the region north of latitude $20^{\circ} \mathrm{N}$ (Figure 2). Conversely in the same period south of latitude $10^{\circ} \mathrm{N}$, there is east-west and north-south circulation believed to be associated with Hadley and Walker circulations, respectively. Starting from May, the tropical easterlies increase quickly as the jet stream moves northward. The jet is intense between latitude $13^{\circ} \mathrm{N}$ and $3^{\circ} \mathrm{S}$ in the months of June through September. There is also an eastward and westward 


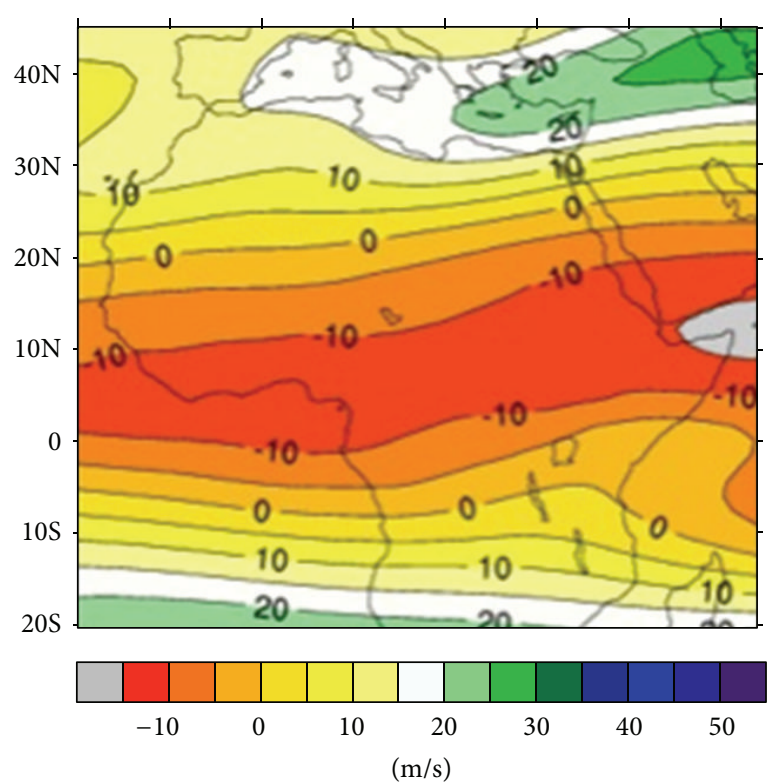

(a) $250 \mathrm{mb}$

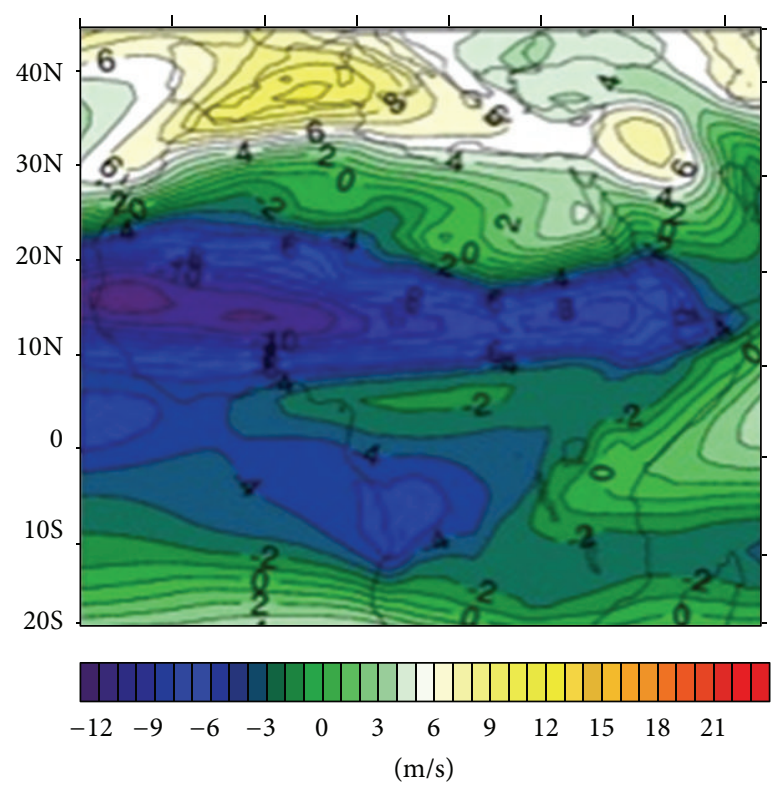

(b) $600 \mathrm{mb}$

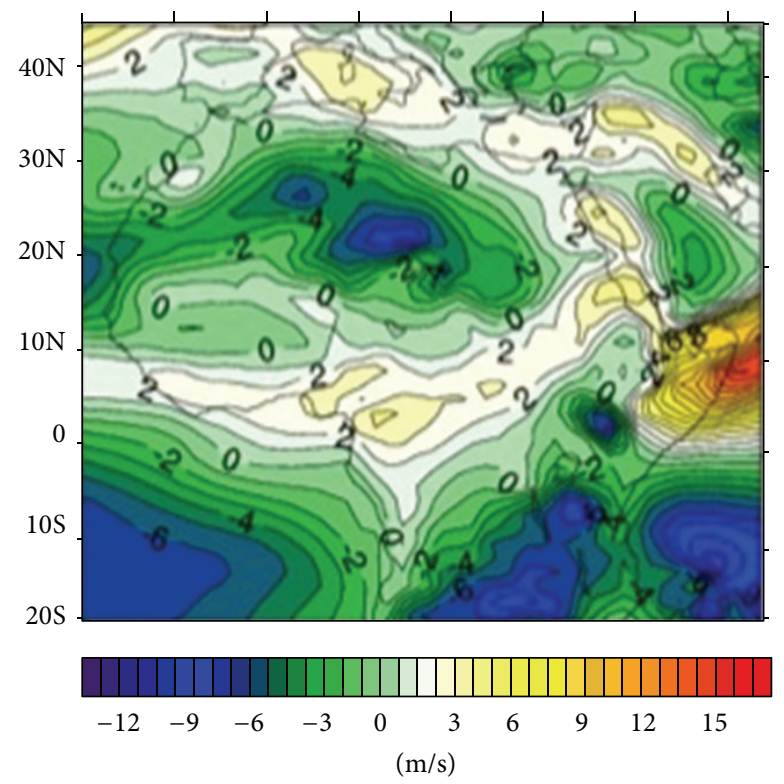

(c) $850 \mathrm{mb}$

Figure 3: Mean wind speed $\left(\mathrm{ms}^{-1}\right.$ ) at (a) $200 \mathrm{mb}$, (b) $600 \mathrm{mb}$, and (c) $850 \mathrm{mb}$ showing the Tropical Easterly Jet, African Easterly Jet, and low-level African Westerly Jet, respectively. Data are from the ERA-Interim reanalysis for a 32-year period from Jan 1979 to Dec 2011.

spilt. This period corresponds to the JJA peak of ascending motion for vertical velocity (not shown). The meridional component of the TEJ may be playing an important role in rainbelt development over this region during the monsoon season by creating a convergence zone around the $200 \mathrm{mb}$ [45]. In this zone, there is a convergence of moisture flux associated with a deep column of moist air (relative humidity of up to $80 \%$ ) and a substantial vertical motion [25]. This results in a favorable environment for convection.

3.2. Interannual Cycle. The interannual variability between wind circulation and rainfall was examined in this section.
The potential association between the interannual variability of wind and rainfall can be revealed by a correlation of their time series. To this end, the monthly mean of each calendar month was averaged from 1979 to 2011 for zonal wind. The computed wind-rainfall correlation was zonally averaged between longitudes $18^{\circ} \mathrm{W}$ and $35^{\circ} \mathrm{E}$ point by point in the time-latitude diagrams. The statistical significance of the results was assessed by applying Student's $t$-test with a degree of freedom given by number of years minus $2(n=32-2)$.

Figure 5 shows the latitude-month distributions of rainfall-wind correlation coefficients. The threshold for statistical significance is 0.4 at $99 \%$ confidence level. For the 

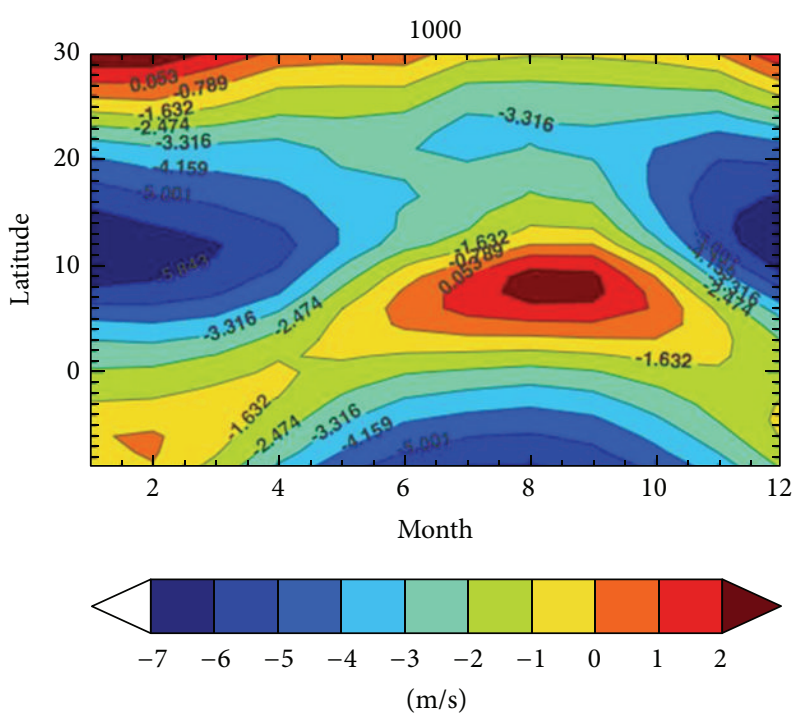

(a)

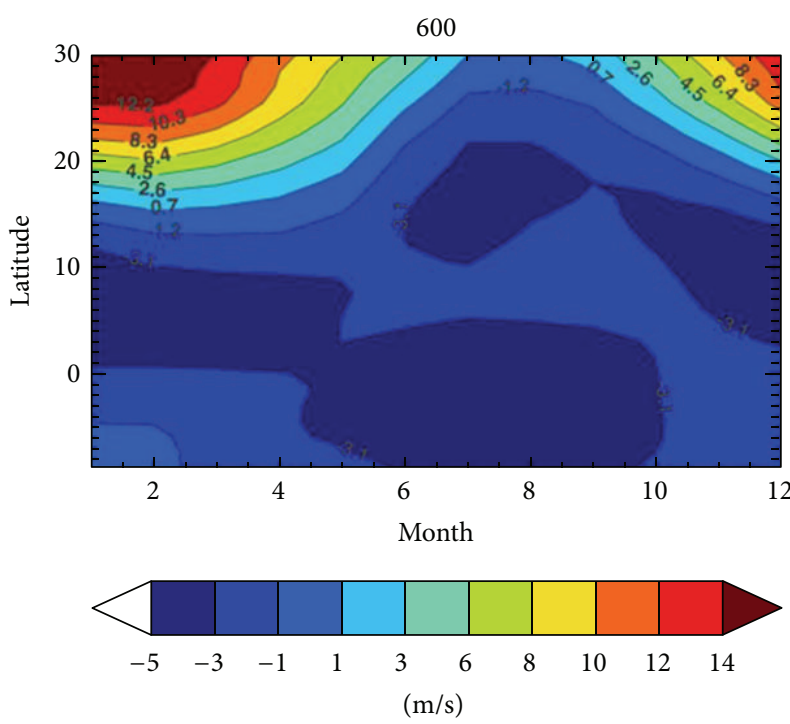

(c)
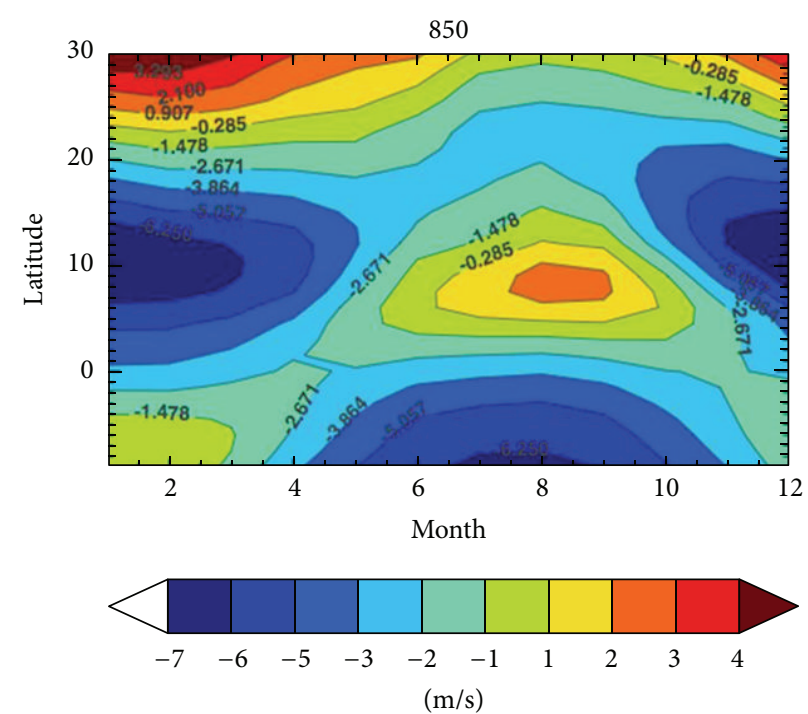

(b)

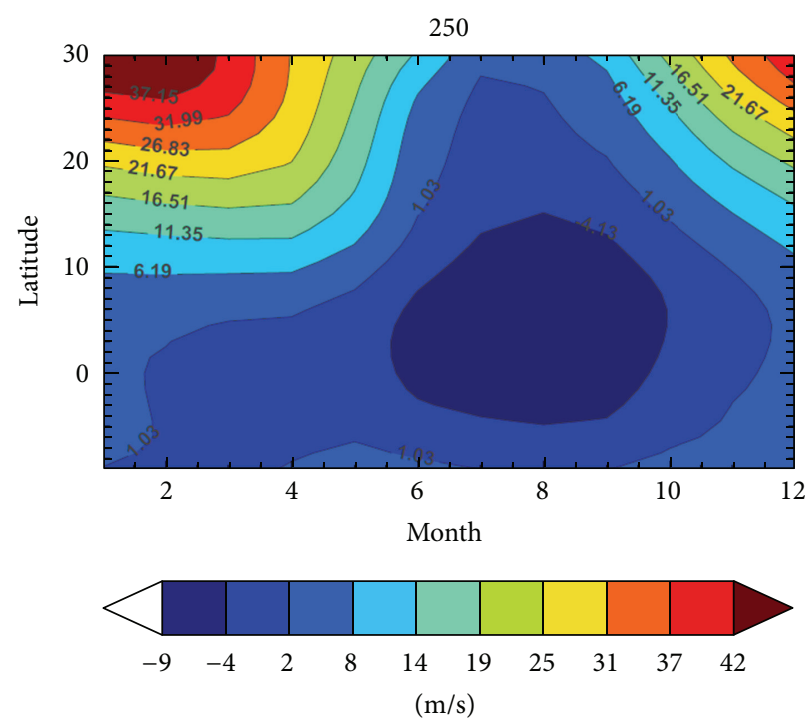

(d)

Figure 4: The seasonal cycle of the zonal-mean wind speed $\left(\mathrm{ms}^{-1}\right.$ ) at (a) $1000 \mathrm{mb}$, (b) $850 \mathrm{mb}$, (c) $600 \mathrm{mb}$, and (d) $200 \mathrm{mb}$, zonally averaged between $18^{\circ} \mathrm{W}$ and $35^{\circ} \mathrm{E}$. Data are from the ERA-Interim reanalysis for a 32-year period from Jan 1979 to Dec 2011.

$250 \mathrm{mb}$ upper tropospheric jet, there is a negative correlation with rainfall south of the equator except in the winter months of November to March. Between equator and latitude $10^{\circ} \mathrm{N}$, there is a very good correlation between precipitation and wind for the months of June to October (Figure 5(a)). On the other hand, the $500 \mathrm{mb}$ zonal wind-rainfall associations show positive correlations south of equator from October to February (Figure 5(b)). There is, however, a statistically significant negative correlation between latitude $8^{\circ}-10^{\circ} \mathrm{S}$ from July to August. During June-September, rainfall association with wind shows a positive correlation in the Sahel region. The $600 \mathrm{mb}$ AEJ produces a positive correlation pattern with rainfall over the Sahel region of West Africa between July and September (Figure 5(c)). From Figure 5(d), it is evident that there is a strong positive relationship between
LLJs and rainfall south of the equator between the months of December and May. This is, however, reversed from the months of June to September. We will examine the variability in the annual cycle of the jests for possible interannual to decadal variability and ENSO association using wavelet analysis in the next section.

3.3. Interannual to Decadal Variability. The nonstationary characteristic of zonal wind both in time and with height is analyzed in this section using the wavelet transform. The results of wavelet analysis of the zonal wind at the pressure levels of the three jet streams are shown in Figures 6 and 7. The standardized time series is shown in the top panel, the middle panel shows the power spectrum based on Morlet wavelet, the bottom panel shows the 2-8 year scaled average, 


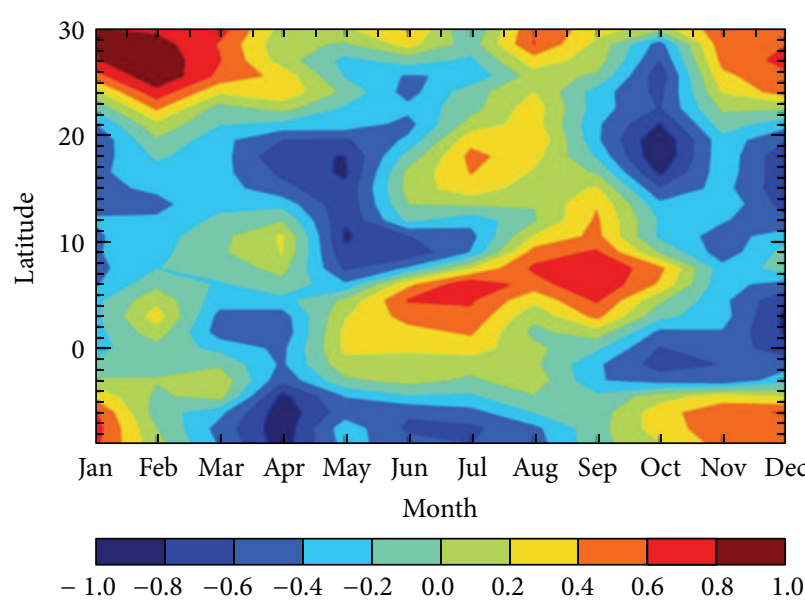

(a)

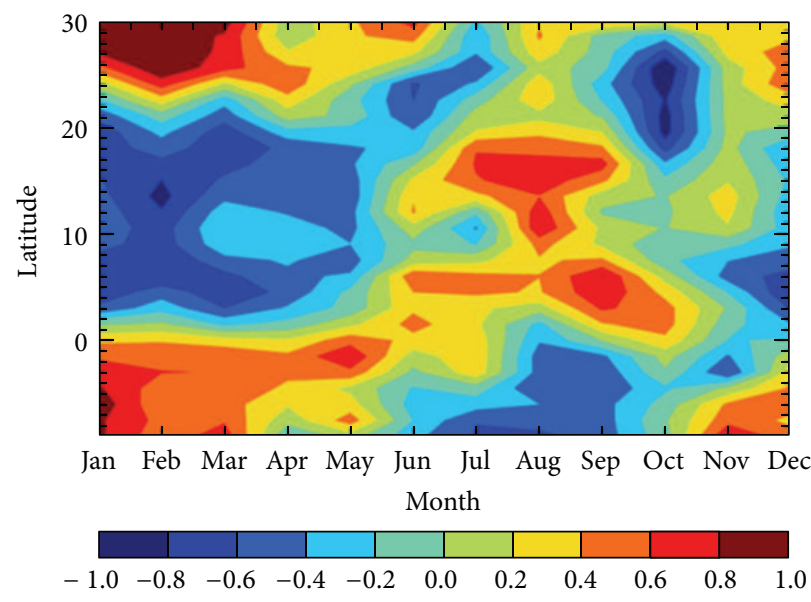

(c)

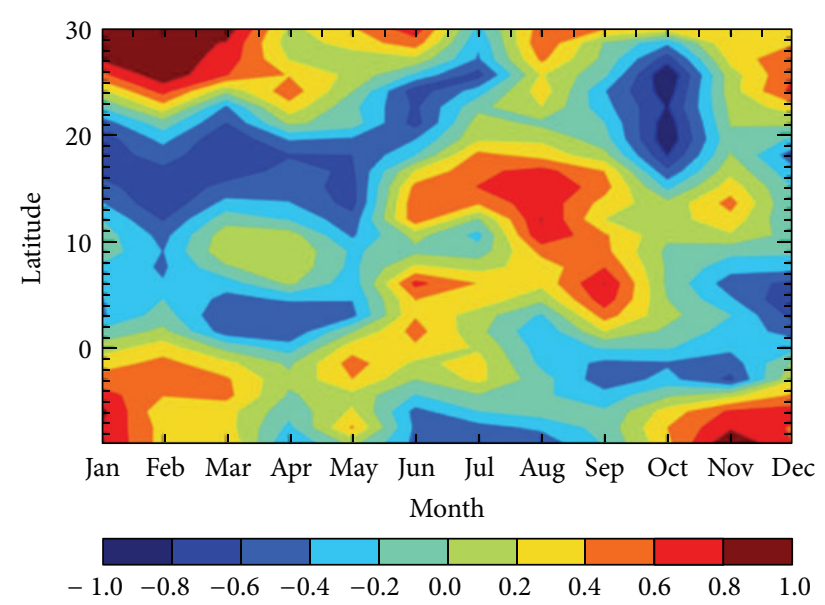

(b)

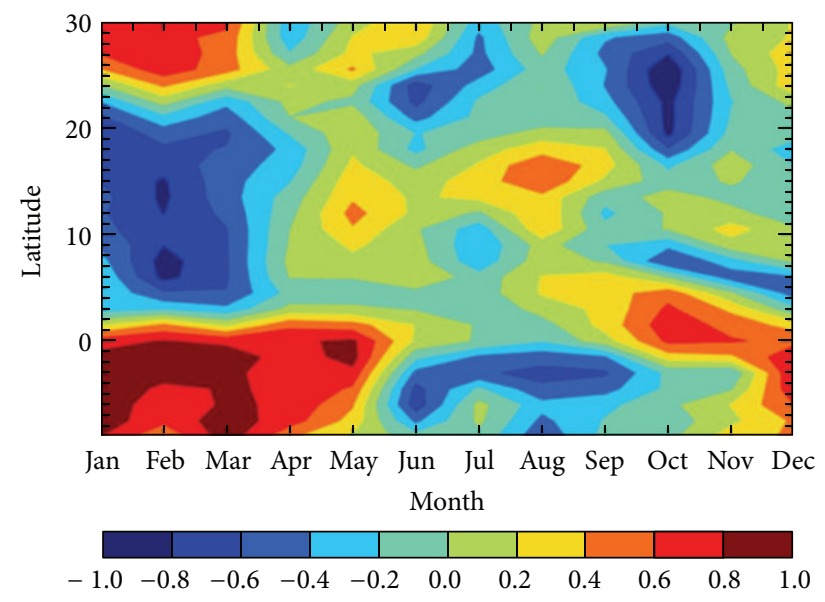

(d)

FIGURE 5: Latitude-month distribution of correlation coefficient between rainfall and wind speeds at (a) $250 \mathrm{mb}$, (b) $500 \mathrm{mb}$, (c) $600 \mathrm{mb}$, and (d) $850 \mathrm{mb}$, zonally averaged between $18^{\circ} \mathrm{W}$ and $35^{\circ} \mathrm{E}$. The threshold for statistical significance is 0.4 at $99 \%$ confidence level.

and the global power spectrum is shown in the side panel. We used the Torrence and Compo [36] Interactive Data Language (IDL) to produce these figures. The global wavelet spectrum provides a consistent and unbiased characterization of the time series variability. The decomposition of the zonal wind time series for the $250 \mathrm{mb}, 500 \mathrm{mb}$, and $600 \mathrm{mb}$ to frequency space in the wavelet power spectrum clearly shows the strong annual signal (Figures 6(a)(B), 6(b)(B), 7(a)(B) and 7(b)(B)) at the 1 year period. For the LLJ at $850 \mathrm{mb}$ (Figure 7(b)(B) middle), however, the annual signal is not as pronounced as the middle to upper tropospheric jets. Rather, it shows the variability of the annual mode with time; with straps of signal in late 80s, early 200s, and just before 2010 (Figure 7(b)(B)). This is consistent with Grist and Nicholson [41] associating its development to wet years (1959-61). According to Grist and Nicholson [41], the LLJs extend to midtroposphere and are in the order of $10 \mathrm{~ms}^{-1}$ in July-September of wet years. In dry years, however, it is almost nonexistent with winds shifting to easterly above the $850 \mathrm{mb}$.

The other significant signal can be seen at the 4-5 year period in the early 1990s for $250 \mathrm{mb}$ and $500 \mathrm{mb}$ (Figures
6(a)(B) and 6(b)(B)) and 1984-1985 for $500 \mathrm{mb}$ and $600 \mathrm{mb}$ (Figures 7(a)(B) and 7(b)(B)). Locally significant power can be seen between 4 and 8 years period from all the jets corresponding to a significant interannual oscillation observed in the late 1990s to 2000 (Figures 6 and 7, middle and bottom). There are also two distinct peaks in the 2-8 year scale average corresponding to the two recent strong ENSO events (198283 and 1997-98). The association between wind and ENSO is statistically significant at a $99 \%$ confidence interval for the $1997 / 1998$ ENSO events. The interannual variability for the LLJ has a lower variance $(0.018)$ for the ENSO year compared to $0.06(500 \mathrm{mb}$ and $600 \mathrm{mb})$ and $0.2(250 \mathrm{mb})$. According to Chen and van Loon [48], the warm phase of Pacific ENSO corresponds to weaker TEJ. The interdecadal variability is evident at scales of 16 and 32 years.

3.4. Cross Wavelet, Coherency, and Phase. The association described in the preceding section is only suggestive of causality between ENSO and the variability of the jet streams. The next step is to expand these time series into frequency space by applying cross wavelet transform (XWT) as a band 


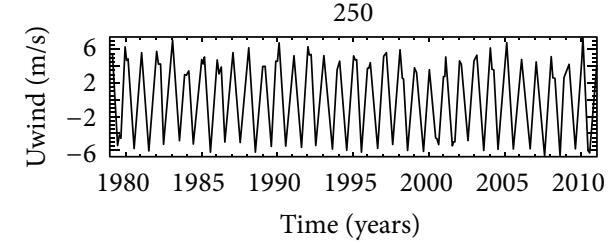

(A) U wind $(\mathrm{m} / \mathrm{s})$

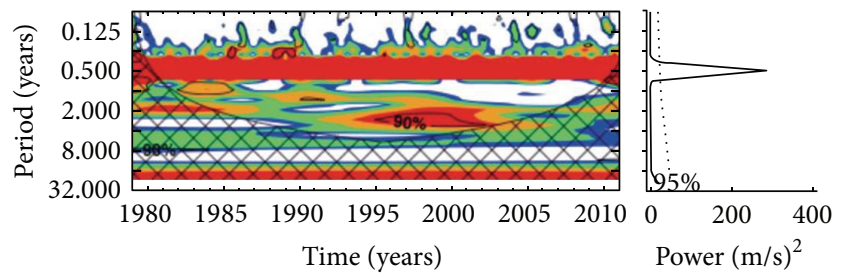

(B) Wavelet power spectrum (contours at $0.5,1,2,4 \mathrm{~m} / \mathrm{s}$ )

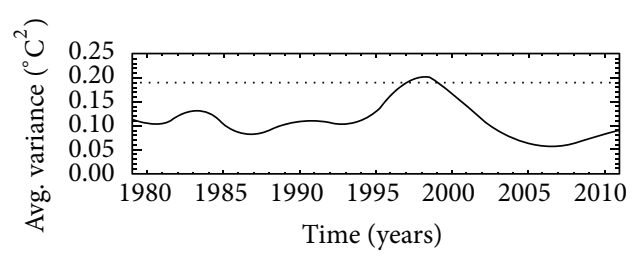

(D) 2-8 year scale-average time series

(a)

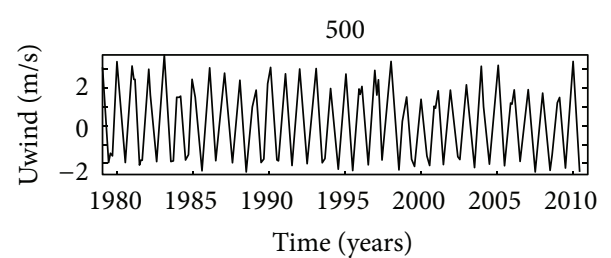

(A) $\mathrm{U}$ wind $(\mathrm{m} / \mathrm{s})$

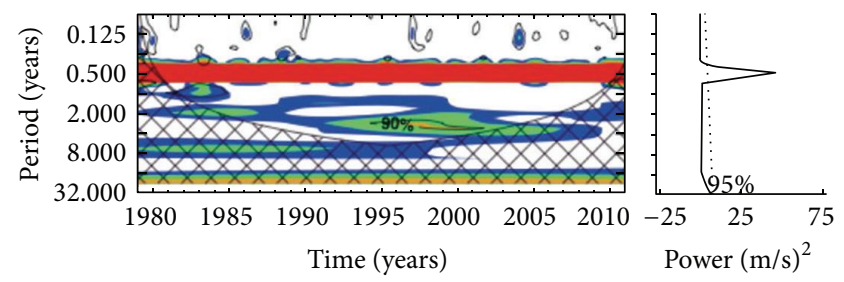

(B) Wavelet power spectrum (contours at $0.5,1,2,4 \mathrm{~m} / \mathrm{s}$ )

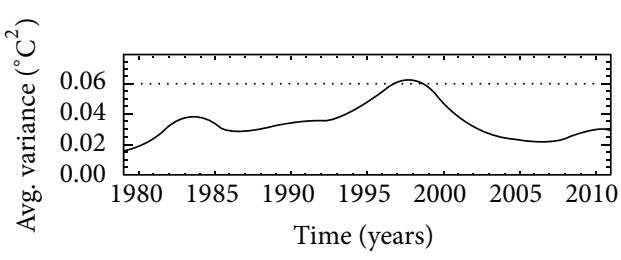

(D) 2-8 year scale-average time series

(b)

FiguRE 6: (a) Monthly $250 \mathrm{mb}$ zonal wind (top) wavelet power spectrum using Morlet wavelet (middle), global wavelet power spectrum (side), and scale averaged wavelet power for a 2-8 year band (bottom). (b) Monthly $500 \mathrm{mb}$ zonal wind (top) wavelet power spectrum using Morlet wavelet (middle), global wavelet power spectrum (side), and scale averaged wavelet power for a 2-8 year band (bottom) (1979-2011). The thick contour enclosed regions are greater than $90 \%$ confidence for a red-noise process. The thin solid line indicates the "cone of influence," where edge effects become important.

filter to the time series. This will help in finding localized periodicities and for feature extraction. The correlation and coherencies will thus be examined in this section. Cross wavelet transform will determine if these associations are merely coincidences by obtaining the frequency component of the jet variability as a function of time. Wavelet transform coherency (WTC) between two XWT will address the statistical significance of the coherences as well as confidence level against noise. In this analysis, we applied the $95 \%$ confidence level.

The XWT and WTC between tropospheric jets and ENSO are shown in Figures 8 and 9. According to Torrence and Compo [36], this is a representation of cross correlation between the variables as a function of time and frequency. The phase difference between the jets and ENSO is represented by the vectors while the locally significant power of the red noise spectrum at a significance level of $\alpha=0.1$ is shown by the bold solid contour line [36]. The lighter black contour line is the cone of influence (COI) where edge effects are not negligible. The coherence power between two series is shown in the color code-red to blue (representing strong to weak, resp.).

The correlation analysis through XWT shows two weak bands that are statistically significant: (1) at the 2-year and
(2) at 4-5 year periods localized at around 2008-2010 and 1983-1987, respectively (Figure 8(a)). The coherency analysis through WCT (Figure 8(b)) shows that the $250 \mathrm{mb}$ tropospheric jet correlated highly with ENSO on the interannual scale at 2 bands: (1) 1-2 year and (2) 4-5 year period localized at 2004-2007 and around 1983 to 1997 years, respectively. There is an in-phase (antiphase) relationship between ENSO and tropospheric jets in the 4-5 year (2-year) periods. According to Grinsted et al. [37], cause and effect relationship in XWT is indicated by phase lock oscillation. Since ENSO and $250 \mathrm{mb}$ jet are in antiphase at the 1-2 year period, it is safe to conclude that ENSO mirrored TEJ during the 2007 strong La Nina year. The 1-2 year covariance is important as it corresponds to years of increasing precipitation across the study domain. Though the correlation at 4-5 year period is weak (Figure $8(\mathrm{a})$ ), the large region that is statistically significant at $95 \%$ confidence level in the WTC (Figure 8(b)), however, suggests that the association is not by chance. However, because the oscillation is not phase locked, we can only speculate that there is a statistically significant association between the strong 1983-1987 ENSO events that led to intense drought in the Sahel region of West Africa and TEJ.

For the $500 \mathrm{mb}$ jet, there is a statistically significant band (Figure $8(\mathrm{c})$ ) in the correlation at the 3-5 year period 


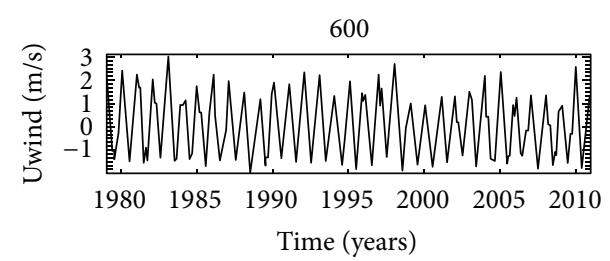

(A) Uwind $(\mathrm{m} / \mathrm{s})$

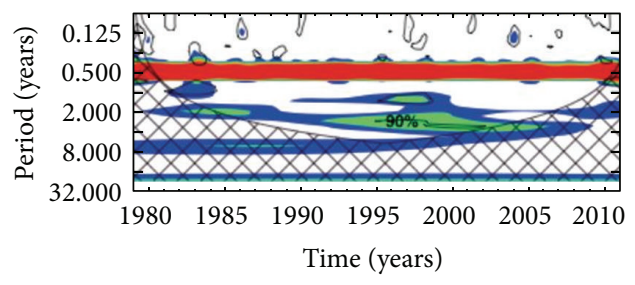

(B) Wavelet power spectrum (contours at $0.5,1,2,4 \mathrm{~m} / \mathrm{s}$ )

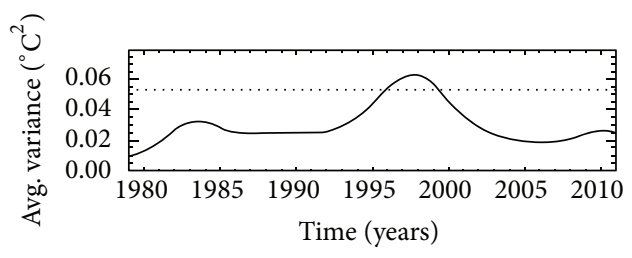

(D) 2-8 year scale-average time series

(a)

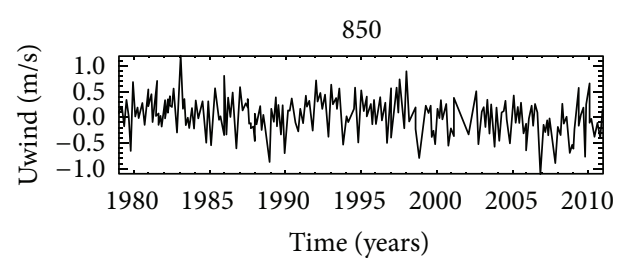

(A) Uwind ( $\mathrm{m} / \mathrm{s})$

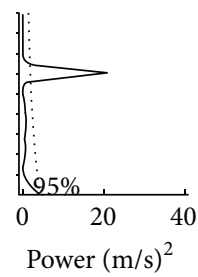

(C) Global
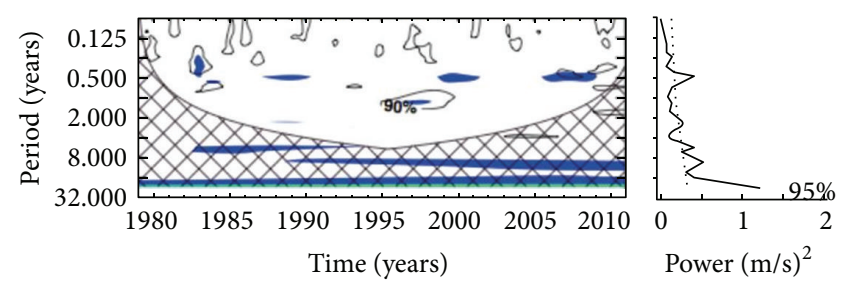

(B) Wavelet power spectrum (contours at $0.5,1,2,4 \mathrm{~m} / \mathrm{s}$ )

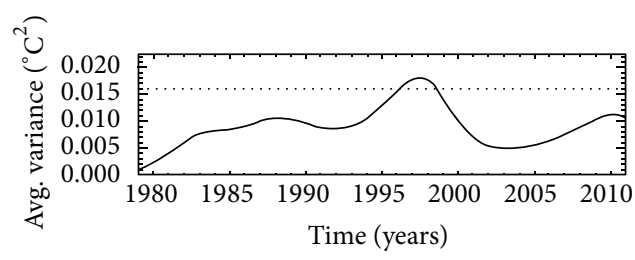

(D) 2-8 year scale-average time series

(b)

Figure 7: Same as in Figure 6 except for (a) $600 \mathrm{mb}$ and (b) $850 \mathrm{mb}$.

localized around 1983-1987. That makes it very unlikely that the association is by chance. For the coherency plot, there are 3 significant bands: (1) 2-year period localized at 1997, (2) 12 year period localized around 2005-2007, and (3) 4-6 year period localized around 1982-1998 (Figure 8(d)). This strong positive covariance between ENSO and $500 \mathrm{mb}$ jet within the 1983-1987 ENSO events indicates a positive association. Also notice that the coherency at the 2-year period is phase locked and also corresponds to the 2007 strong La Nina year.

The $600 \mathrm{mb}$ correlation analysis through XWT has only one band (6-year period) that is statistically significant (Figure 9(a)). This 6 year periodicity has less significant power but phase is locked. As a result, we can only speculate a strong link between ENSO and AEJ. ENSO spectral coherence is very strong in 2 bands: (1) the 1-2 year period in 1997 and (2) the 1-2 year period around 2005-2007 (Figure 9(c)). These bands highlight an important capability of wavelet coherency in extracting features with minimal power, yet high coherency. The spectral coherency in the $4-5$ year period localized around 1983-1990 is in-phase.

The association between low-level jets $(850 \mathrm{mb})$ and ENSO shows phase angles that are phase-locked in the 56 year period localized around 1986-1993 (Figure 9(b)). The region that is statistically significant at a $95 \%$ confidence level in the WTC at the periodicity of 6-8year period (Figure 9(d)), however, suggests that the association is not by chance. The 2007 moderate La Niña year of 2007 shows a statistically significant coherence with ENSO in the $600 \mathrm{mb}$ and $850 \mathrm{mb}$ jets. These associations are also phase locked suggesting that the association is not by chance either (Figure 9(d)).

These results support earlier reports of the role of ENSO in modulating Sahel rainfall [20, 22, 49, 50]. Tropical Easterly Jet (TEJ) has been reported to be weaker in the El Nino years [48]. An and Wang (2005) [51] also reported that the upper-level jet stream associated with ENSO mode intensified over the subtropical northeastern Pacific. Some unresolved issues concern the possible processes and physical mechanisms relating ENSO to jet streams that explain the rainfall anomalies in the western Sahel region.

\section{Conclusions}

In this study, we used ERA-Interim 1979-2011 dataset to (1) examine the latitude-month annual, interannual, and decadal variability in West African Jet streams between latitude $10^{\circ} \mathrm{S}$ and $20^{\circ} \mathrm{N}$ zonally averaged over the longitudinal domain $18 \mathrm{~W}-34 \mathrm{E}$, (2) to examine the climatologically, spatial, and temporal distribution of the correlation between $250 \mathrm{mb}$, $500 \mathrm{mb}, 600 \mathrm{mb}$, and $850 \mathrm{mb}$ zonal wind and precipitation, (3) to assess the linkages between synoptic-scale circulation and multidecadal variations in precipitation characteristics for the study domain, and (4) to explore the teleconnection patterns between ENSO and interannual to multidecadal variability in jet streams. 


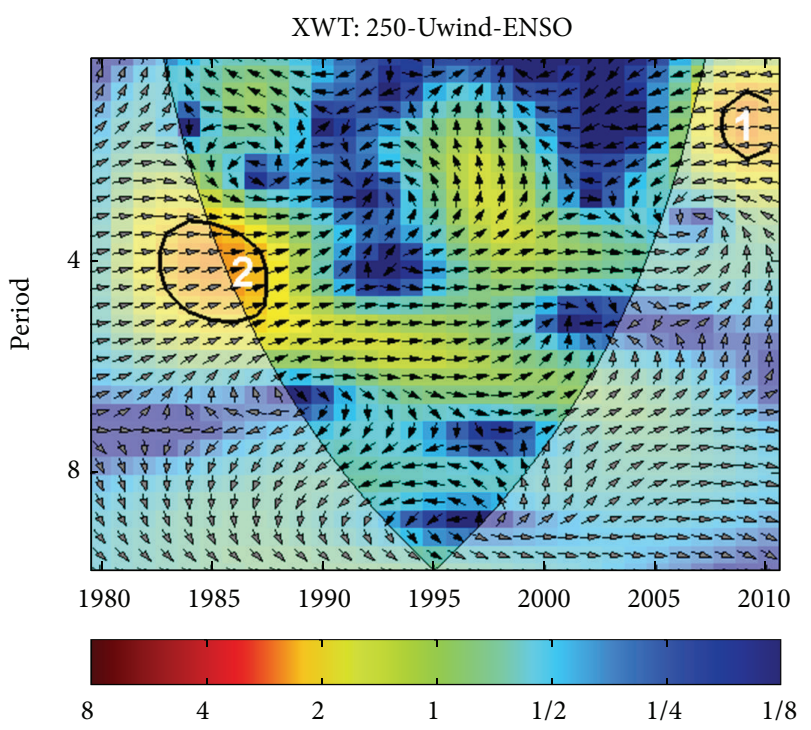

(a)

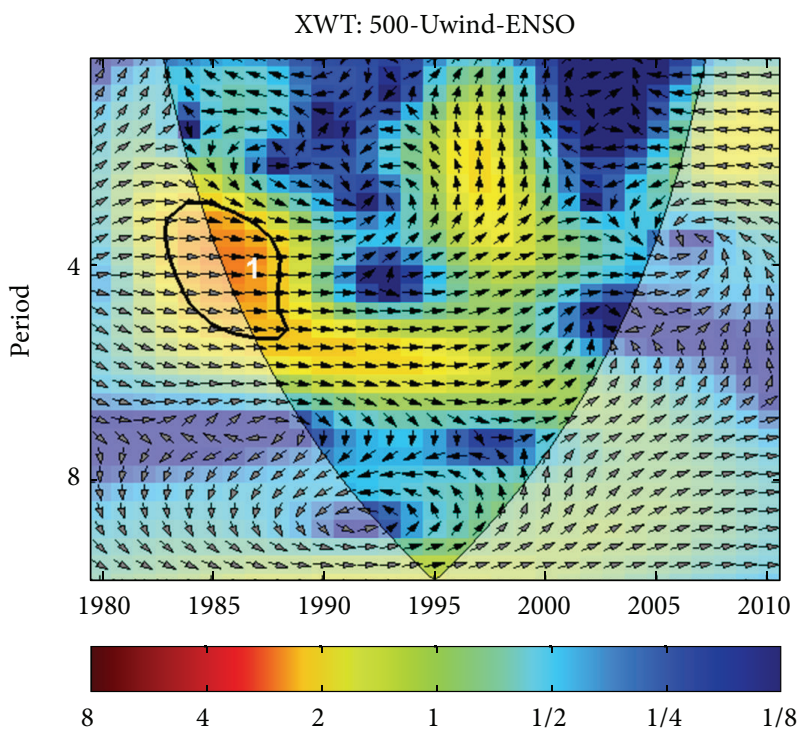

(c)

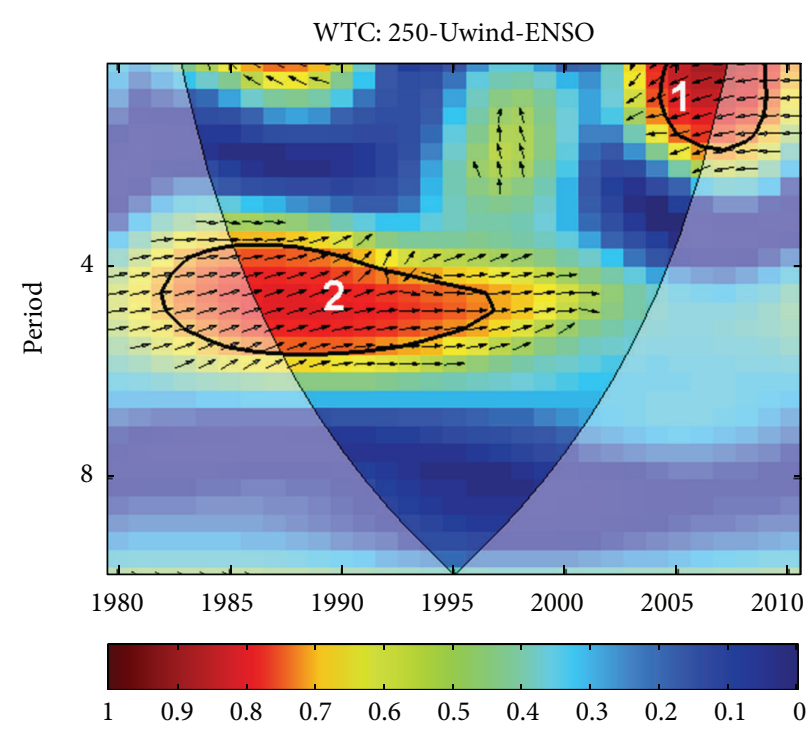

(b)

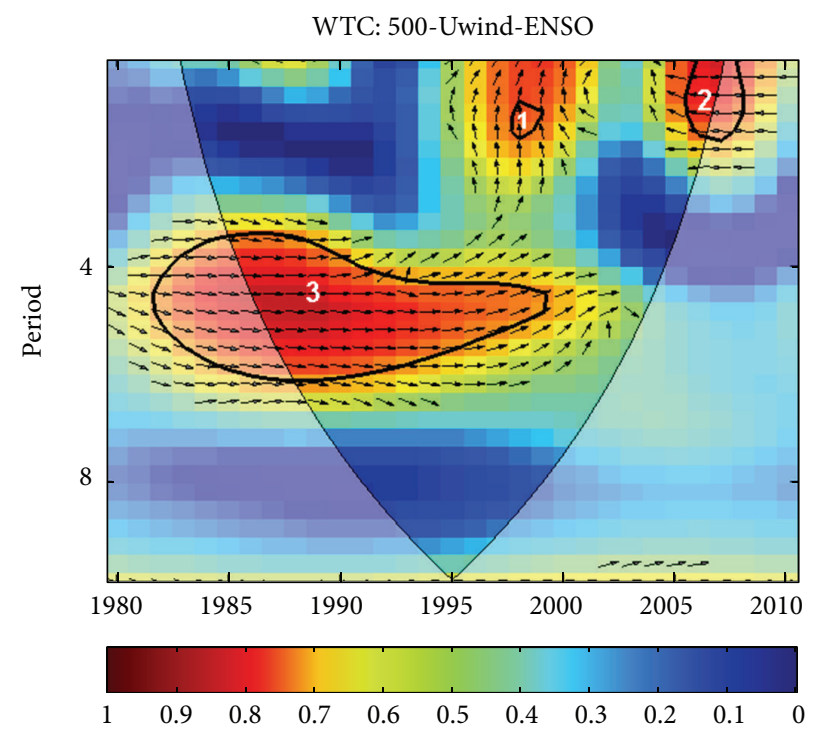

(d)

Figure 8: ENSO and wind cross wavelet spectrum (a) $250 \mathrm{mb}$ and (c) $500 \mathrm{mb}$ and wavelet coherence (b) $250 \mathrm{mb}$ and (d) $500 \mathrm{mb}$ (in-phase pointing right, antiphase pointing left, leading by $90^{\circ}$ pointing straight down; see text for details and interpretation). The thick contour enclosed regions are greater than $95 \%$ confidence for a red-noise process. The thin solid line indicates the "cone of influence," where edge effects become important.

We summarize our results as follows.

(1) The low-level African Westerly Jet (AWJ) correlates well with rainfall south of the equator in the winter month; the Tropical Easterly Jet (TEJ) and African Easterly Jet (AEJ) correlate better with rainfall north of the equator in the summer months.

(2) The study also shows considerable multidecadal variability in the relationship between ENSO and troposheric jets. In addition, the interannual-to-decadal variability in $200 \mathrm{mb}, 600 \mathrm{mb}$, and $850 \mathrm{mb}$ of $U$ wind reveals that there is enhanced variability in the 28 year period.
(3) The 2007 moderate La Niña year shows a statistically significant coherence with ENSO in the $500 \mathrm{mb}$, $600 \mathrm{mb}$, and $850 \mathrm{mb}$ jets.

(4) There is a statistically significant association between the strong 1983-1987 ENSO events that led to intense drought in the Sahel region of West Africa and TEJ.

This work is potentially interesting because of the implications for understanding the dynamical mechanisms driving precipitation variability over Tropical Africa and their connection with remote processes, for example, the ENSO impact on large scale circulation and jet streams. Advancing the understanding of variability in rainfall and climate forcing 


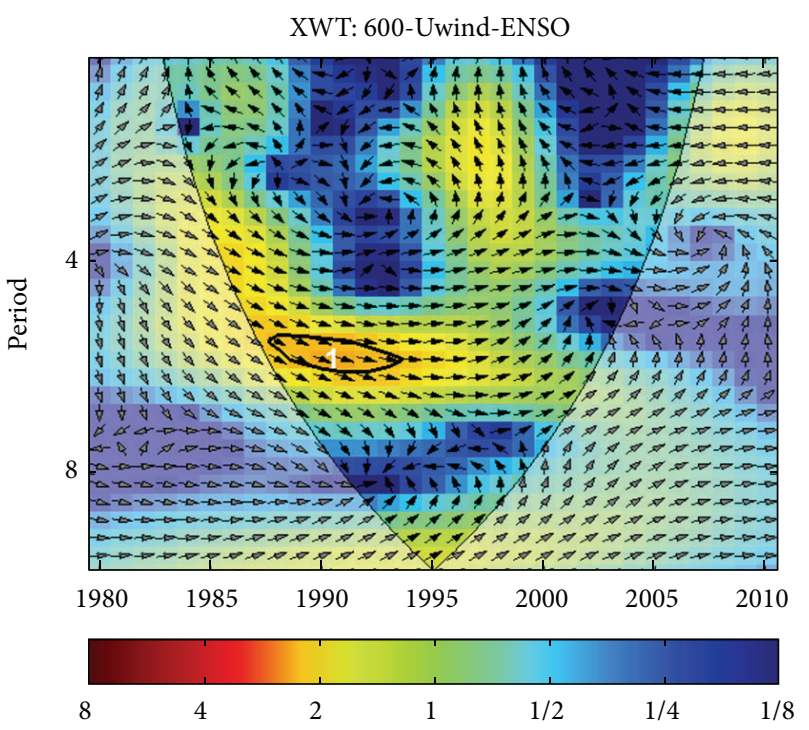

(a)

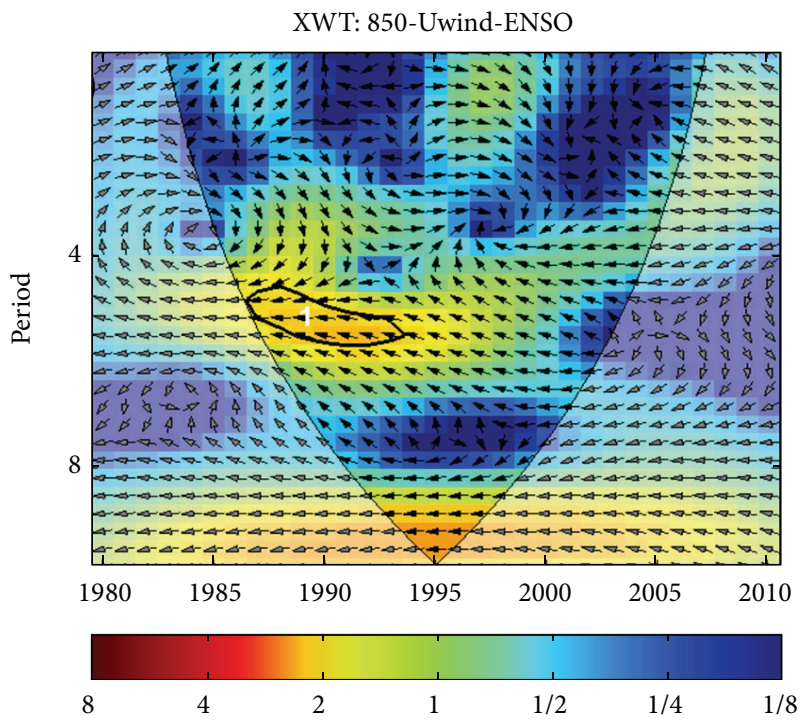

(b)

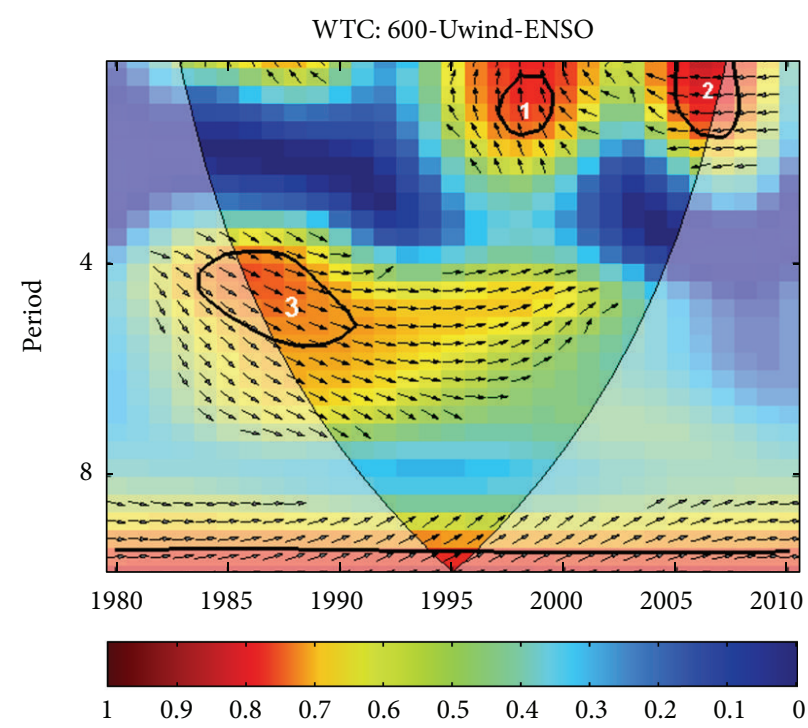

(c)

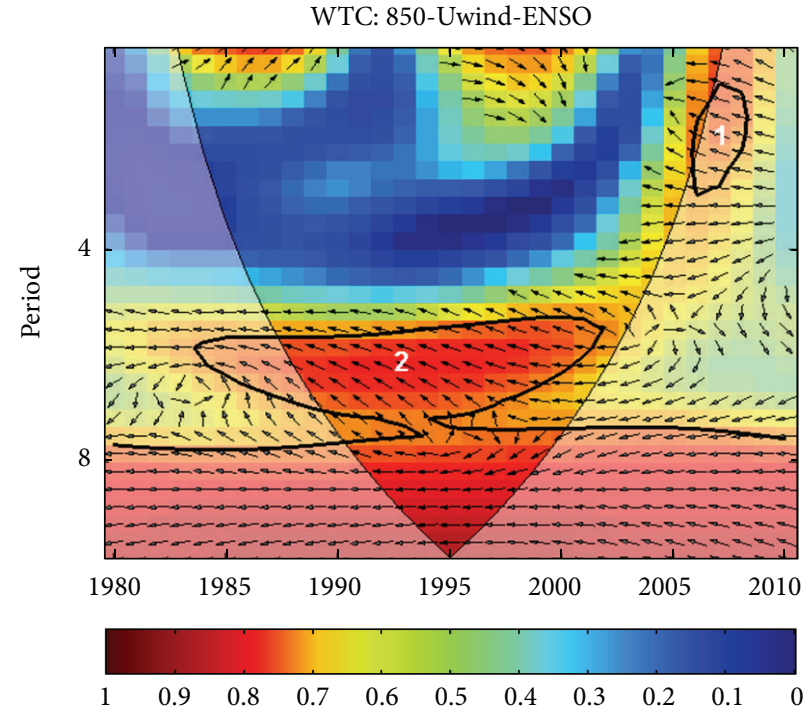

(d)

Figure 9: ENSO and wind cross wavelet spectrum (a) $600 \mathrm{mb}$ and (c) $850 \mathrm{mb}$ and wavelet coherence (b) $600 \mathrm{mb}$ and (d) $850 \mathrm{mb}$ (in-phase pointing right, antiphase pointing left, leading by $90^{\circ}$ pointing straight down; see text for details and interpretation). The thick contour enclosed regions are greater than $95 \%$ confidence for a red-noise process. The thin solid line indicates the "cone of influence," where edge effects become important.

in this region could therefore improve the accuracy of rainfall forecast and estimation. With the establishment of a statistically significant relationship between ENSO and jet streams in West African Sahel, Characterization of ENSO effect atmospheric dynamics at the microclimate scale in Sahel regionwill be explored next.

\section{Conflict of Interests}

The authors declare that there is no conflict of interests regarding the publication of this paper.

\section{Acknowledgments}

The authors wish to acknowledge the support of Beltsville Center for Climate Systems Observations (BCCSO) and the National Oceanic and Atmospheric Administration (NOAA) Center for Atmospheric Sciences (NCAS), both at Howard University. This research was partly supported by the Project "Interactions and Feedbacks between Biomass Burning and Water Cycle Dynamics across the Northern Sub-Saharan African Region," funded by NASA under the ROSES-2009 Interdisciplinary Studies (IDS) Program and managed by Dr. Hal Maring. 


\section{References}

[1] A. Giannini, R. Saravanan, and P. Chang, "Oceanic forcing of Sahel rainfall on interannual to interdecadal time scales," Science, vol. 302, no. 5647, pp. 1027-1030, 2003.

[2] C. M. Taylor, E. F. Lambin, N. Stephenne, R. J. Harding, and R. L. H. Essery, "The influence of land use change on climate in the Sahel," Journal of Climate, vol. 15, no. 24, pp. 3615-3629, 2002.

[3] J. G. Charney, "Dynamics of deserts and drought in the Sahel," Quarterly Journal of Royal Meteorological Society, vol. 101, no. 428, pp. 193-202, 1975.

[4] Y.X. Yongkang Xue and J. Shukla, "The influence of land surface properties on Sahel climate. Part I: desertification," Journal of Climate, vol. 6, no. 12, pp. 2232-2245, 1993.

[5] K. Y. Li, M. T. Coe, N. Ramankutty, and R. D. Jong, "Modeling the hydrological impact of land-use change in West Africa," Journal of Hydrology, vol. 337, no. 3-4, pp. 258-268, 2007.

[6] J. F. Reynolds and D. M. Stafford, Do Humans Cause Deserts? Global Desertification: Do Humans Cause Deserts, 2002.

[7] L. Eklundh and L. Olsson, "Vegetation index trends for the African Sahel 1982-1999," Geophysical Research Letters, vol. 30, no. $8,2003$.

[8] L. Polgreen, "In Niger, trees and crops turn back the desert," New York Times, February 2007.

[9] S. M. Herrmann, A. Anyamba, and C. J. Tucker, "Recent trends in vegetation dynamics in the African Sahel and their relationship to climate," Global Environmental Change, vol. 15, no. 4, pp. 394-404, 2005.

[10] M. Biasutti, I. M. Held, A. H. Sobel, and A. Giannini, "SST forcings and Sahel rainfall variability in simulations of the twentieth and twenty-first centuries," Journal of Climate, vol. 21, no. 14, pp. 3471-3486, 2008.

[11] A. Giannini, R. Saravanan, and P. Chang, "Dynamics of the borealsummer African monsoon in the NSIPP1 atmospheric model," Climate Dynamics, vol. 25, no. 5, pp. 517-535, 2005.

[12] A. Giannini, M. Biasutti, and M. M. Verstraete, "A climate model-based review of drought in the Sahel: desertification, the re-greening and climate change," Global and Planetary Change, vol. 64, no. 3-4, pp. 119-128, 2008.

[13] S. E. Nicholson, "The West African Sahel: a review of recent studies on the rainfall regime and its interannual variability," ISRN Meteorology, vol. 2013, Article ID 453521, 32 pages, 2013.

[14] C. K. Folland, T. N. Palmer, and D. E. Parker, "Sahel rainfall and worldwide sea temperatures, 1901-85," Nature, vol. 320, no. 6063, pp. 602-607, 1986.

[15] J. Lu and T. L. Delworth, "Oceanic forcing of the late 20th century Sahel drought," Geophysical Research Letters, vol. 32, no. 22, Article ID L22706, pp. 1-5, 2005.

[16] M. Hoerling, J. Hurrell, J. Eischeid, and A. Phillips, "Detection and attribution of twentieth-century northern and southern African rainfall change," Journal of Climate, vol. 19, no. 16, pp. 3989-4008, 2006.

[17] I. Polo, A. Ullmann, P. Roucou, and B. Fontaine, "Weather regimes in the Euro-Atlantic and Mediterranean sector, and relationship with West African rainfall over the 1989-2008 period from a self-organizing maps approach," Journal of Climate, vol. 24, no. 13, pp. 3423-3432, 2011.

[18] I. Polo, B. Rodríguez-Fonseca, T. Losada, and J. García-Serrano, "Tropical atlantic variability modes (1979-2002). Part I: timeevolving SST modes related to West African rainfall," Journal of Climate, vol. 21, no. 24, pp. 6457-6475, 2008.
[19] C. E. Chung and V. Ramanathan, "Weakening of north Indian SST gradients and the monsoon rainfall in India and the Sahel," Journal of Climate, vol. 19, no. 10, pp. 2036-2045, 2006.

[20] D. P. Rowell, "Teleconnections between the tropical Pacific and the Sahel," Quarterly Journal of the Royal Meteorological Society, vol. 127, no. 575, pp. 1683-1706, 2001.

[21] C. Caminade and L. Terray, "Twentieth century sahel rainfall variability as simulated by the ARPEGE AGCM, and future changes," Climate Dynamics, vol. 35, no. 1, pp. 75-94, 2010.

[22] M. Joly, A. Voldoire, H. Douville, P. Terray, and J.-F. Royer, "African monsoon teleconnections with tropical SSTs: validation and evolution in a set of IPCC4 simulations," Climate Dynamics, vol. 29, no. 1, pp. 1-20, 2007.

[23] L. M. Druyan, "Studies of 21st-century precipitation trends over West Africa," International Journal of Climatology, vol. 31, no. 10, pp. 1415-1424, 2011.

[24] S. E. Nicholson, "On the factors modulating the intensity of the tropical rainbelt over West Africa," International Journal of Climatology, vol. 29, no. 5, pp. 673-689, 2009.

[25] R. Zhang and T. L. Delworth, "Impact of Atlantic multidecadal oscillations on India/Sahel rainfall and Atlantic hurricanes," Geophysical Research Letters, vol. 33, no. 17, Article ID L17712, 2006.

[26] C. D. Thorncroft, H. Nguyen, C. Zhang, and P. Peyrille, "Annual cycle of the West African monsoon: regional circulations and associated water vapour transport," Quarterly Journal of the Royal Meteorological Society, vol. 137, no. 654, pp. 129-147, 2011.

[27] J. H. Christensen, T. R. Carter, M. Rummukainen, and G. Amanatidis, "Evaluating the performance andutility of regional climate models: the PRUDENCE project," Climatic Change, vol. 81, no. 1, pp. 1-6, 2007.

[28] J. F. Griffiths, Climate of Africa, vol. 10 of World Survey of Climatology, Elsevier, 1972.

[29] S.-Y. Wang and R. R. Gillies, "Observed change in Sahel rainfall, circulations, African easterly waves, and Atlantic hurricanes since 1979," International Journal of Geophysics, vol. 2011, Article ID 259529, 14 pages, 2011.

[30] A. Simmons, S. Uppala, D. Dee, and S. Kobayashi, "ERAInterim: new ECMWF reanalysis products from 1989 onwards," ECMWF Newsletter, vol. 110, no. 110, pp. 25-35, 2007.

[31] D. P. Dee, S. M. Uppala, A. J. Simmons et al., “The ERA-Interim reanalysis: configuration and performance of the data assimilation system," Quarterly Journal of the Royal Meteorological Society, vol. 137, no. 656, pp. 553-597, 2011.

[32] J.-N. Thépaut, "Assimilating only surface pressure observations in 3D and 4DVar," in Proceedings of the ECMWF Workshop on Atmospheric Reanalysis, pp. 107-112, ECMWF, Reading, UK, June 2006.

[33] J. S. Whitaker, G. P. Compo, and J.-N. Thépaut, "A comparison of variational and ensemble-based data assimilation systems for reanalysis of sparse observations," Monthly Weather Review, vol. 137, no. 6, pp. 1991-1999, 2009.

[34] J. E. Janowiak, A. Gruber, C. R. Kondragunta, R. E. Livezey, and G. J. Huffman, "A comparison of the NCEP-NCAR reanalysis precipitation and the GPCP rain gauge-satellite combined dataset with observational error considerations," Journal of Climate, vol. 11, no. 11, pp. 2960-2979, 1998.

[35] X.-Z. Liang and W.-C. Wang, "Associations between China monsoon rainfall and tropospheric jets," Quarterly Journal of the Royal Meteorological Society, vol. 124, no. 552, pp. 2597-2623, 1998. 
[36] C. Torrence and G. P. Compo, "A practical guide to wavelet analysis," Bulletin of the American Meteorological Society, vol. 79, no. 1, pp. 61-78, 1998.

[37] A. Grinsted, J. C. Moore, and S. Jevrejeva, "Application of the cross wavelet transform and wavelet coherence to geophysical times series," Nonlinear Processes in Geophysics, vol. 11, no. 5-6, pp. 561-566, 2004.

[38] C. Kidd, E. Dawkins, and G. Huffman, "Comparison of precipitation derived from the ECMWF operational forecast model and satellite precipitation data sets," Journal of Hydrometeorology, vol. 14, pp. 1463-1482, 2013.

[39] N. M. J. Hall, G. N. Kiladis, and C. D. Thorncroft, "Threedimensional structure and dynamics of African easterly waves. Part II: dynamical modes," Journal of the Atmospheric Sciences, vol. 63, no. 9, pp. 2231-2245, 2006.

[40] A. K. Dezfuli and S. E. Nicholson, "A note on long-term variations of the African easterly jet," International Journal of Climatology, vol. 31, no. 13, pp. 2049-2054, 2011.

[41] J. P. Grist and E. Nicholson, "A study of the dynamic factors influencing the rainfall variability in the West African Sahel," Journal of Climate, vol. 14, no. 7, pp. 1337-1359, 2001.

[42] B. Pu and K. H. Cook, "Dynamics of the West African westerly jet," Journal of Climate, vol. 23, no. 23, pp. 6263-6276, 2010.

[43] J.-B. Stuut, M. Zabel, V. Ratmeyer et al., "Provenance of presentday eolian dust collected off NW Africa," Journal of Geophysical Research D, vol. 110, no. 4, Article ID D04202, pp. 1-14, 2005.

[44] E. A. Afiesimama, "Annual cycle of the mid-tropospheric easterly jet over West Africa," Theoretical and Applied Climatology, vol. 90, no. 1-2, pp. 103-111, 2007.

[45] S. E. Nicholson and J. P. Grist, "The seasonal evolution of the atmospheric circulation over West Africa and equatorial Africa," Journal of Climate, vol. 16, no. 7, pp. 1013-1030, 2003.

[46] T.-C. Chen, "Maintenance of the midtropospheric North African summer circulation; Saharan high and African easterly jet," Journal of Climate, vol. 18, no. 15, pp. 2943-2962, 2005.

[47] R. J. Cornforth, B. J. Hoskins, and C. D. Thorncroft, "The impact of moist processes on the African Easterly Jet-African Easterly Wave system," Quarterly Journal of the Royal Meteorological Society, vol. 135, no. 641, pp. 894-913, 2009.

[48] T. C. Chen and H. van Loon, "Interannual variation of the tropical easterly jet," Monthly Weather Review, vol. 115, no. 8, pp. 1739-1759, 1987.

[49] S. Janicot and B. Sultan, "Intra-seasonal modulation of convection in the West African monsoon," Geophysical Research Letters, vol. 28, no. 3, pp. 523-526, 2001.

[50] T. Losada, B. Rodríguez-Fonseca, E. Mohino, J. Bader, S. Janicot, and C. R. Mechoso, "Tropical SST and Sahel rainfall: a nonstationary relationship," Geophysical Research Letters, vol. 39, Article ID L12705, 2012.

[51] S.-I. An and B. Wang, "The forced and intrinsic low-frequency modes in the North Pacific," Journal of Climate, vol. 18, no. 6, pp. 876-885, 2005. 

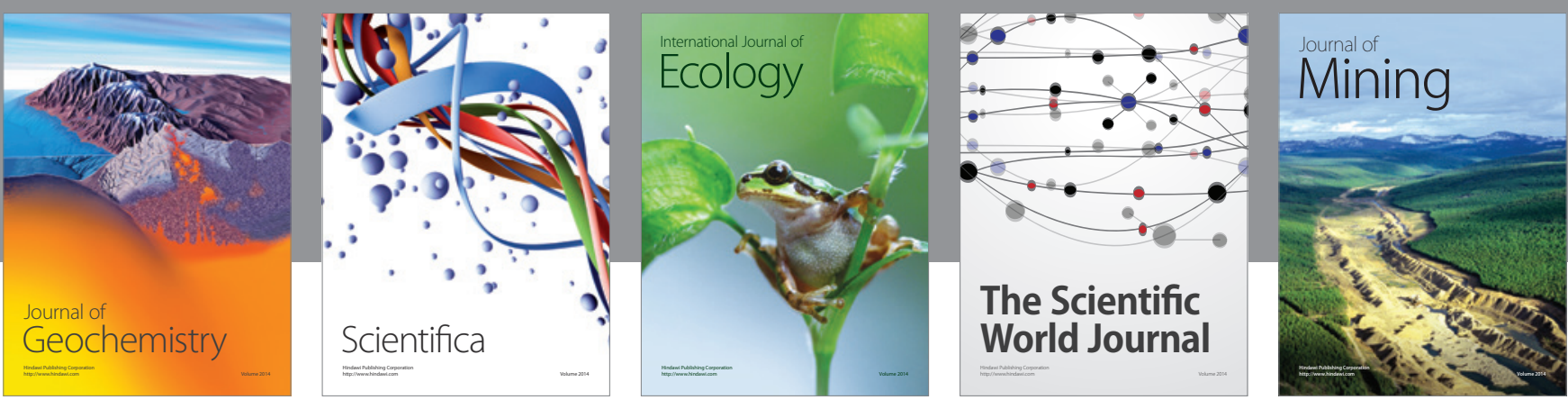

The Scientific World Journal
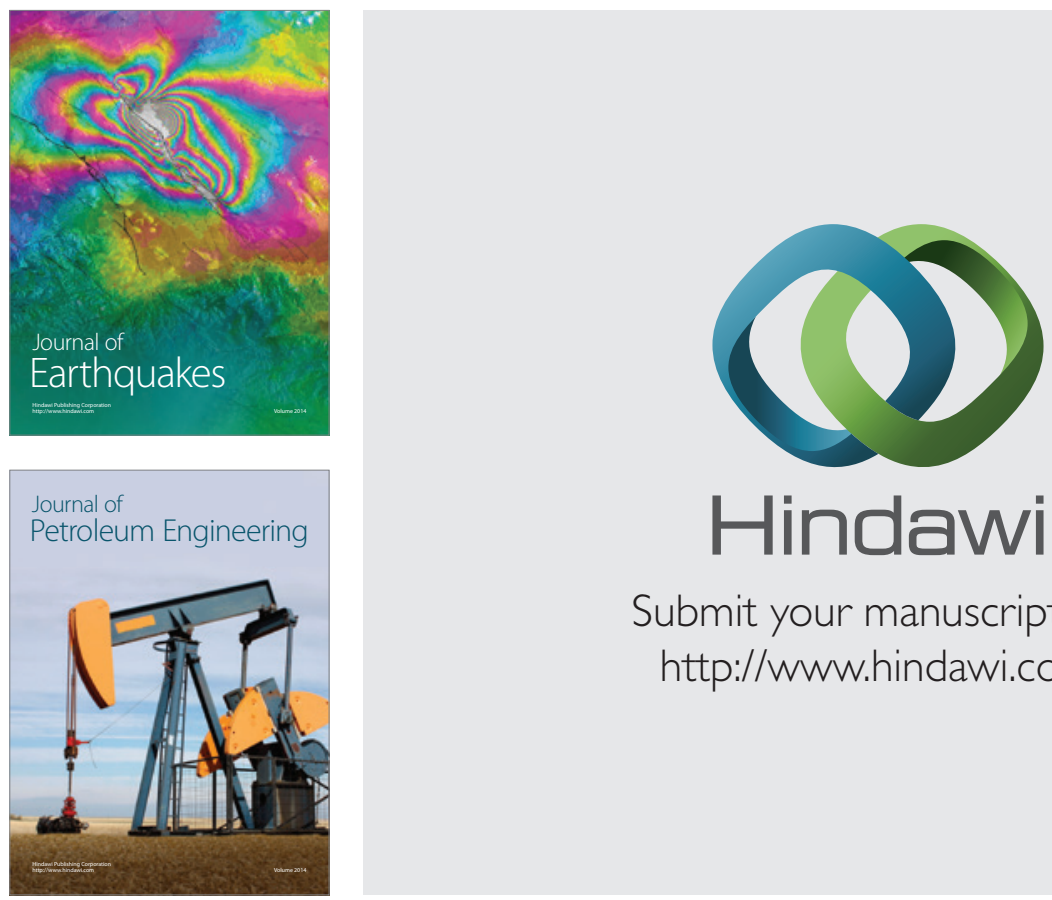

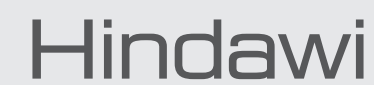

Submit your manuscripts at

http://www.hindawi.com
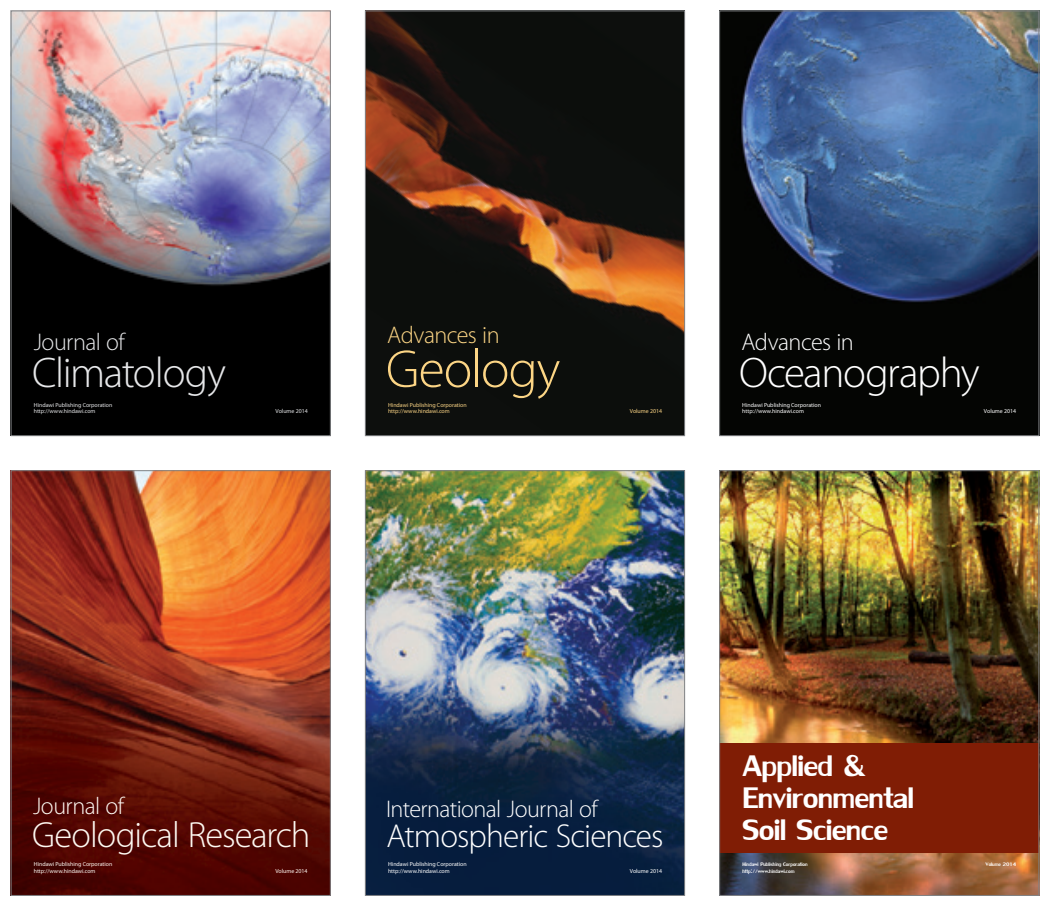
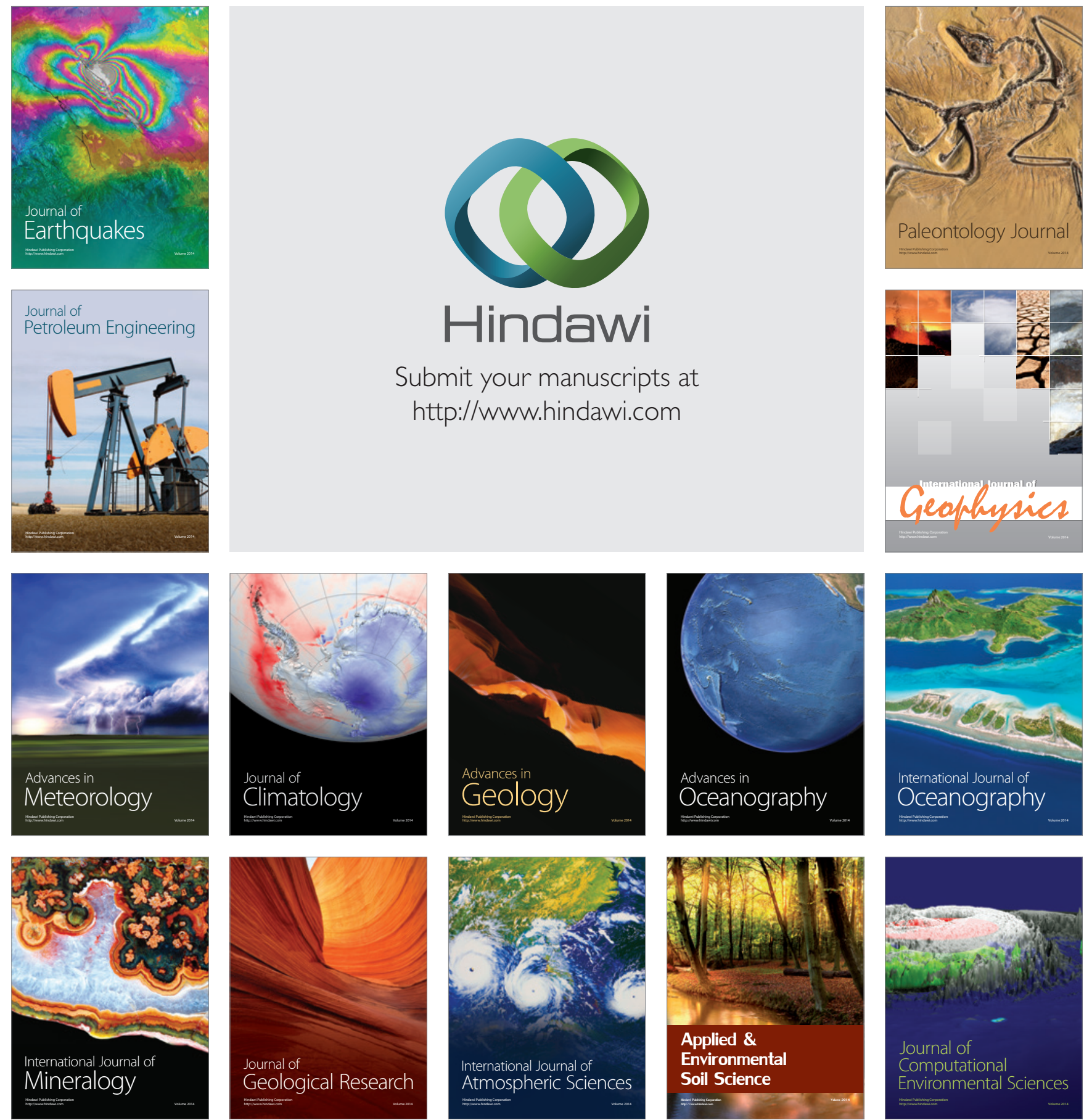